\title{
The Local Wisdom-Based STEM Worksheet to Enhance the Conceptual Understanding of Pre-service Physics Teacher
}

\author{
Indri Sari Utami ${ }^{1, \mathrm{a})}$, Mudmainah Vitasari ${ }^{2, \mathrm{~b})}$, Indah Langitasari ${ }^{3, \mathrm{c})}$, \\ Iwan Sugihartono ${ }^{4}$, Yuli Rahmawati ${ }^{5}$
}

\begin{abstract}
${ }^{1}$ Physics Education, Faculty of Teacher Training and Education, Sultan Ageng Tirtayasa University, Serang, Banten, 42117, Indonesia

${ }^{2}$ Science Education, Faculty of Teacher Training and Education, Sultan Ageng Tirtayasa University, Serang, Banten, 42117, Indonesia

${ }^{3}$ Chemistry Education, Faculty of Teacher Training and Education, Sultan Ageng Tirtayasa University, Serang, Banten, 42117, Indonesia

${ }^{4}$ Physics, Faculty of Mathematics and Natural Sciences, Universitas Negeri Jakarta, Jakarta Timur, 13220, Indonesia

${ }^{5}$ Chemistry Education, Faculty of Mathematics and Natural Sciences, Universitas Negeri Jakarta, Jakarta Timur, 13220, Indonesia

凹: a)isu_indrisariutami@untirta.ac.id, b)mdvitasari@untirta.ac.id, c)indahlangitasari@untirta.ac.id
\end{abstract}

\begin{abstract}
The STEM (Science, Technology, Engineering, Mathematics) approach plays an important role in developing students' abilities. The ability to combine science, technology, technical expertise, and mathematics is a tool that can help human life can be created. Of course, the application of STEM needs to be assisted by teaching materials in the form of Worksheets. With the STEM implementation worksheet, it can be more easily implemented without the lecturer having to explain each material fully. Because it must be students who develop their abilities. Following constructivist learning theory, by constructing one's knowledge, the knowledge will be stored longer in memory. The ability in STEM is also very important in the current era of globalization. With the rapid advancement of technology, each individual is required to continue to innovate in developing a technology product. The basic ability that students need to have in learning basic physics is to understand a concept. A good understanding of the concept will be very supportive when prospective teachers later teach. It is expected that through the application of STEM, students are directly involved actively in designing and making products, and understanding concepts can be better. Products made by students must be really needed so that they can be used every day. It is better if the product utilizes local wisdom that is around the student environment. The product to be made is to convert the abundant solar thermal energy in Serang into a heater that can be used for cooking. It is a renewable energy because the heat in Serang is sweltering up to $32^{\circ} \mathrm{C}$, so it can be used more than just drying. Based on these needs, mak a worksheet STEM based on local wisdom needs to be applied in learning. The results of this study stated that the local wisdom-based STEM worksheet on temperature and heat material for Physics teacher candidates was developed as a learning medium to increase students' interest and understanding through independent learning.
\end{abstract}

Keywords: local wisdom, STEM, understanding of concepts 


\section{INTRODUCTION}

Learning is an individual process in constructing knowledge to achieve a goal. So learning must be done with a process that is meaningful for each student. Meaningful learning can increase the understanding of each student's concepts. Understanding the concept is very dependent on the conceptions students have about their ideas about the content and meaning of a concept obtained from various information (Wang et al. 2017) (Gunawan et al. 2018). The learning process can provide valuable information for students if the teacher provides a meaningful process for exploring a concept. A good understanding of concepts can be a foundation for students to practice other abilities needed for an individual.

Meaningful learning to be able to improve students' understanding of concepts must make students as the center of learning. In addition to meaningful learning, learning should be done effectively and fun. Effective and fun learning can be supported by teaching materials used in learning (Afifah \& Ellianawati 2019). Teachers must plan the learning process well, in order to achieve the goal of understanding students with the material to be conveyed (Afifah \& Ellianawati 2019).

Teaching materials that are able to guide students to find their knowledge without continuing to ask the instructor are worksheets (Yulkifli et al. 2019). Stages in the worksheet students must follow the flow. It is used to find their concepts. Worksheets make the learning process interesting and can guide students to construct their knowledge following the expected competencies (Asmawati 2015) (Astusi \& Setiawan 2013). Proper steps in the worksheet will be able to guide students to achieve the competencies that teachers expect. So worksheets must be arranged based on teaching material, expected competencies, and conditions of students.

Currently, learning innovations are widely used for the realization of increasing students' abilities towards 21st-century abilities. One that is in the spotlight is STEM (Science, Technology, Engineering, and Mathematics). The STEM learning is learning that is more connected and relevant, able to develop ideas that are constructive and reflective so that it is not just memorizing concepts, but rather on understanding the concepts of science and relationships in life to realize better the importance of protecting the environment (Sthohlmann, Moore, \& Roehrig 2012; Afriana, Permanasari, \& Fitriani 2016; Pertiwi, Abdurrahman, \& Rosidin 2017; Dewi 2017). The development of technology requires the current generation of more literate technology to make it not only as a user. With STEM learning, students can understand the concept of the material to apply it in the manufacture of technology products. Then the physics teacher candidates should consider mastery technology as a means to provide better physics teaching (Muliyati et al. 2019) and need to be equipped with the application of STEM learning so that students who are taught are able to implement the knowledge they can participate in class to solve problems in life.

Improving the quality of teaching and learning outcomes in STEM learning can be done by choosing the right learning approach. It offers a way to help students achieve the required mastery by maximizing class time dedicated to problem-solving and deep conceptual understanding (Bazelais \& Doleck 2018). The conceptual knowledge is the understand the core principles and relating them. There are two critical aspects of instructional practices that help students develop conceptual understanding: allowing students to struggle with problems, and discussing conceptual relationships explicitly (O'Dwyer et al. 2015).

Mastery of concepts and technological knowledge possessed by someone is needed by each region, especially the area where he lives. The wealth of an area can be developed if the young generation is willing to preserve and introduce it outside the region. For this reason, in learning, it is necessary to link regional local wisdom to be raised so that it is better known. Local wisdom is the knowledge that comes from experience and local wisdom. Local wisdom is found in the community (Nurdiansah et al. 2018). Local wisdom is the knowledge that has been proven valid in context and locally accumulated by local communities community (Nurdiansah et al. 2018). Linking wisdom by raising the problem of local wisdom can make students able to think openly to explore local wisdom in their area. Introducing local wisdom to students can also increase student awareness in understanding more about the area where they live. The local wisdom values integration in learning strategies enhance the students' positive character (Parwati et al. 2017). Based on the observations of Jufrida et al., students have an interest if the learning material is integrated with the local wisdom of the area (Jufrida et al. 2019). 
Local wisdom of an area wrapped with technology can increase students' understanding of the concept of a concept or material. A good understanding of concepts can require students to create a work of technology that can answer problems around their lives so that the formation of students' knowledge of a concept must be started and arranged themselves. So that understanding is stored long in their memory to be developed into more in-depth knowledge.

Material temperature and heat are closely related to daily life, so students must master well to be able to solve problems in their lives related to the material. Much potential can be developed from temperature and heat to become a technology product. So that the need for motivation and good guidance to shape the conception of students to fit the conceptions of the experts.

Based on these backgrounds, a local wisdom-based STEM Worksheet is needed to be used as an alternative in increasing the understanding of the concept of prospective physics teachers on temperature and heat.

\section{METHODS}

This study use research and development methods, which are generally known as Research and Development $(R \& D)$. This study uses the ADDIE development model (Analyze, Design, Development, Implementation, Evaluation) (Branch 2009). The steps of development research undertaken to develop this local wisdom-based STEM worksheet are as follows.

\section{Analysis Phase (Analyze )}

At this stage, an analysis of the needs of the STEM worksheet based on local wisdom is needed to obtain data about the needs of this worksheet. The number of core respondents is 60 students. Obtained results $87 \%$ of students need this worksheet. Then a literature analysis was conducted on the development of worksheets, such as the results of this study.

\section{Stage Design ( Design )}

At this stage, the worksheet design is done through literature study, material analysis, media analysis, and guidance with experts. So that from this stage, the stages produced in the worksheet and local wisdom presented in the worksheet.

\section{Development Phase (Development)}

At this stage of development, the worksheets were developed following the STEM approach and then linked to the local wisdom of the inner Baduy community in Banten. Then the development that has been done is guided and validated by experts. Validation is done by media experts, material experts, and learning experts. The completion of worksheets was carried out in accordance with expert input.

\section{Implementation Phase (Implementation)}

At this stage, a trial was conducted on students regarding this local wisdom-based STEM worksheet. From implementation, the increase of students' understanding of the concept seen.

\section{Stage Evaluation (Evaluation)}

At this stage, the worksheet is improved based on the results of the implementation that has been done. This is done to improve worksheets in order to achieve the expected goals and motivate students to learn.

\section{RESULT AND DISCUSSION}

The first meeting was given a pretest question to see the level of understanding of students' concepts before learning. After that, the second meeting of the students was given a worksheet that presented 
problems to motivate them to learn to find solutions to the problems by integrating STEM. After introductory learning is given, students try to solve problems with the guidance of worksheets. The lecturer becomes their facilitator if there is filling out a worksheet that is not well understood. Then at the next meeting, students test and make the tools they have designed to solve the problem at the previous meeting. Here students do practical work to test the success of the tools they make. The fourth meeting of each group presented the results of the tools they made and how they worked together with their development plans. In this meeting, the lecturer confirmed the concepts that had been expressed by the students. Here the conception of students is equated with the conception of physicists. So that if there is a misconception, it can be corrected. The fifth meeting is a posttest activity to test students' understanding of concepts after learning. By using the pretest, evaluation questions can be seen changes in the understanding of student concepts.

Worksheets are created to guide students in exploring concepts. So the lecturer or instructor does not do much lecture method. By figuring out their knowledge, it is hoped that the knowledge obtained by students can last longer. Discussion with a group of friends is also expected to improve the socialization of new students for the better.

Worksheets that are made present a narrative story that illustrates the circumstances surrounding students who can introduce local wisdom. The local wisdom is brought to be explored by the potential students after the story is presented, several questions that can explore the problems that can be fixed in the area. Through several questions, students are expected to find the best solution in exploring the natural potential in their area and solving problems through STEM integration expected by the lecturer or instructor. Through the questions, students are also asked to mention and formulate what technology they can make to solve the problem.

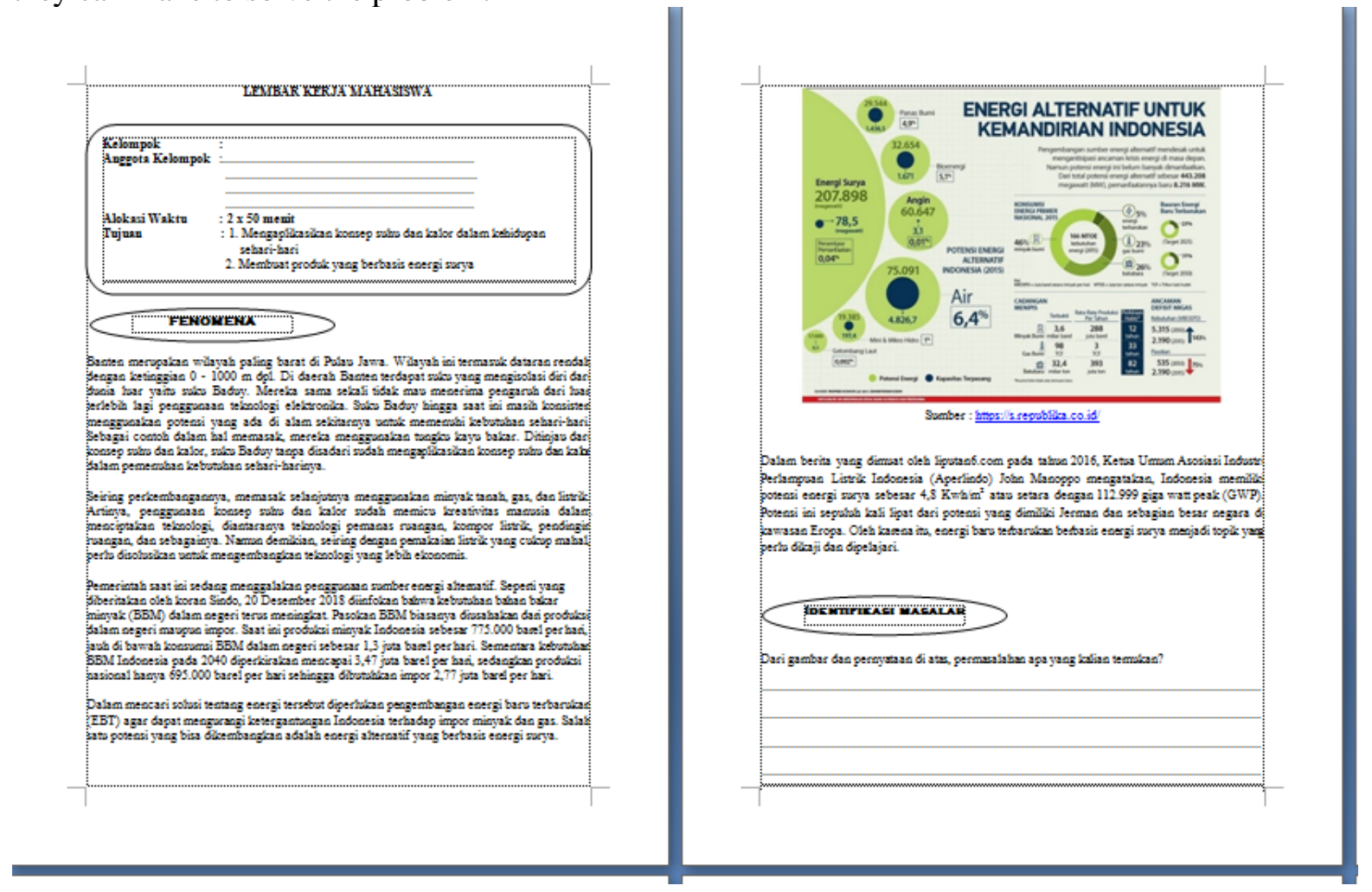

FIGURE 1. Presentation of Problems in a Worksheet

Through open-ended questions, students can explore their knowledge, which at the same time also trains high-level thinking skills. As stated by Miliken and Adams in Halim (2012), the STEM approach can train students to apply and integrate the concepts of science, technology, engineering, and mathematics to solve problems creatively and innovatively. Ejiwale (2012) also stated that the application of STEM was able to increase the mastery of knowledge and also apply it in problemsolving. 
After leading students' opinions to solve problems with STEM integration, students are led to make mini proposals in worksheets. The purpose of the mini proposal is a proposed plan that will be developed by students.

The second worksheet is a tool testing worksheet. Worksheets only contain questions about how students design experiments to test the tools they make so that they can think more openly without the details of the stages of activities that are usually present in practical instructions.

Observation tables are also students themselves who make with short instructions from worksheets. These brief instructions conclude the steps of product testing, observation tables, graphs obtained to the conclusions of the experiment. After that, in the worksheet, ask students to make a report on the technology tools they made and present them at the next meeting.
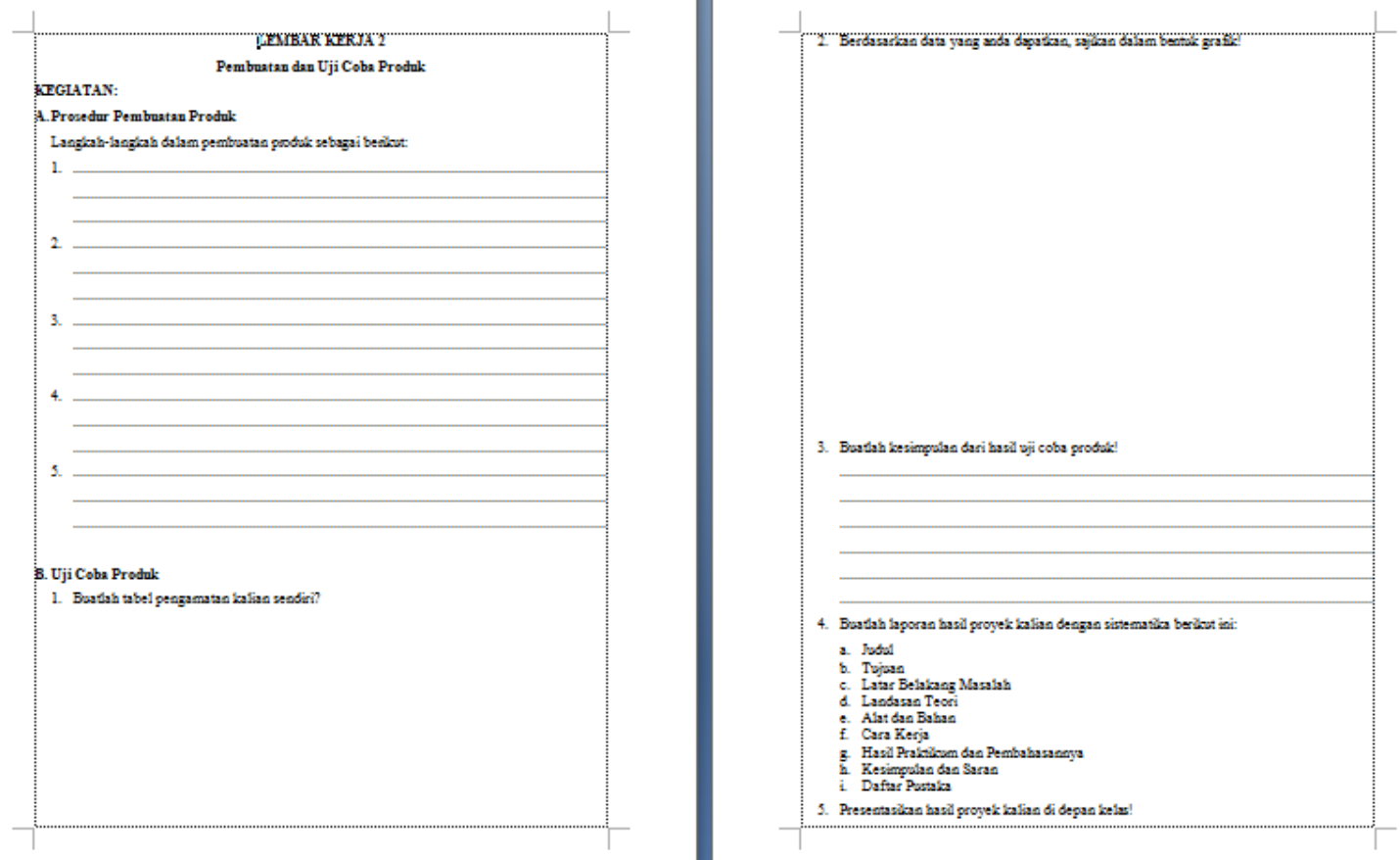

FIGURE 2. Worksheet 2 guiding the preparation of the proposal.

This worksheet testing is carried out during basic physics lecture hours. This study was conducted four times, each with two credits ( $2 \times 50$ minutes). Pretests are given at the first meeting to measure students' initial conceptual understanding. $\mathrm{H}$ acyl pretest can be used as a reference to see the level of understanding of the concept of beginning students on the topic of temperature and heat for pretest running well and smoothly.

In the second meeting, the participants were given a presentation on the material temperature and heat as a provision for students to make products that apply this material. Explanation of temperature and heat material starts from the notion of temperature, thermometric properties, how to make and calibrate thermometers, expansion, heat, to heat transfer - submission of material using PowerPoint media, whiteboards, and markers.

At the second meeting, the students were given a STEM-based worksheet to guide students discussing with a group of friends about the application of temperature and heat material to be better understood. The worksheet starts from the presentation of natural phenomena that become local wisdom in Banten, then presents data on natural resources that are not yet utilized by humans. From there, they find their problems by connecting problems in the Baduy area of Banten with natural resources that are still rarely utilized. From these problems, each group discusses to produce a product that can be a solution to the problem that they revealed previously connected with the material temperature and heat. Each group plans to make a different product as a solution to solve the problem. After that, students are asked to work on making their products outside of class hours for one week. 


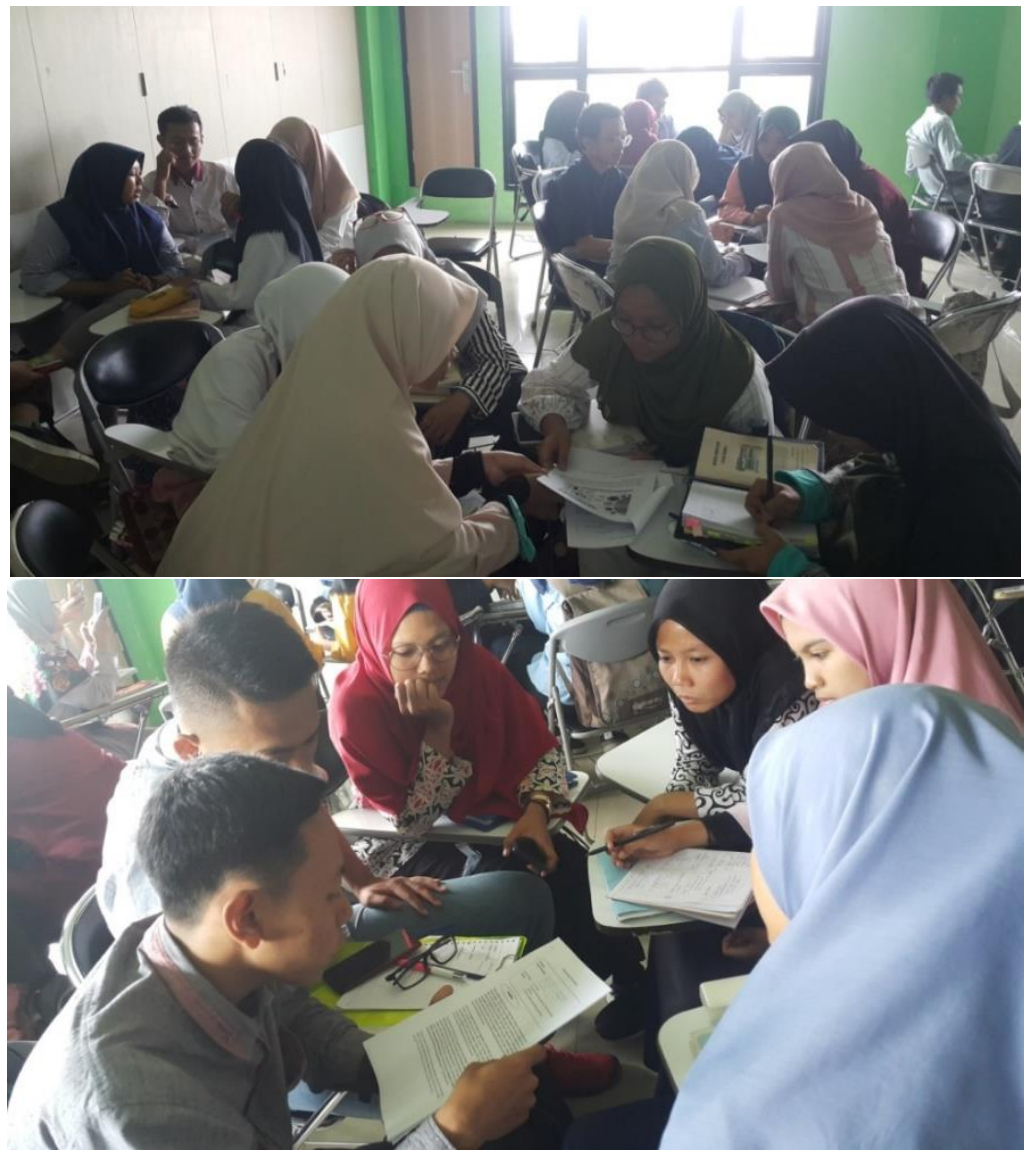

FIGURE 3. Each group discusses worksheets.

The third meeting of each group presented the results of the products they made. They explained the difficulties in making products, how the products work, to the advantages and disadvantages of the product. Then in the question and answer session, the other groups of students asked questions to enter how the product should be repaired.
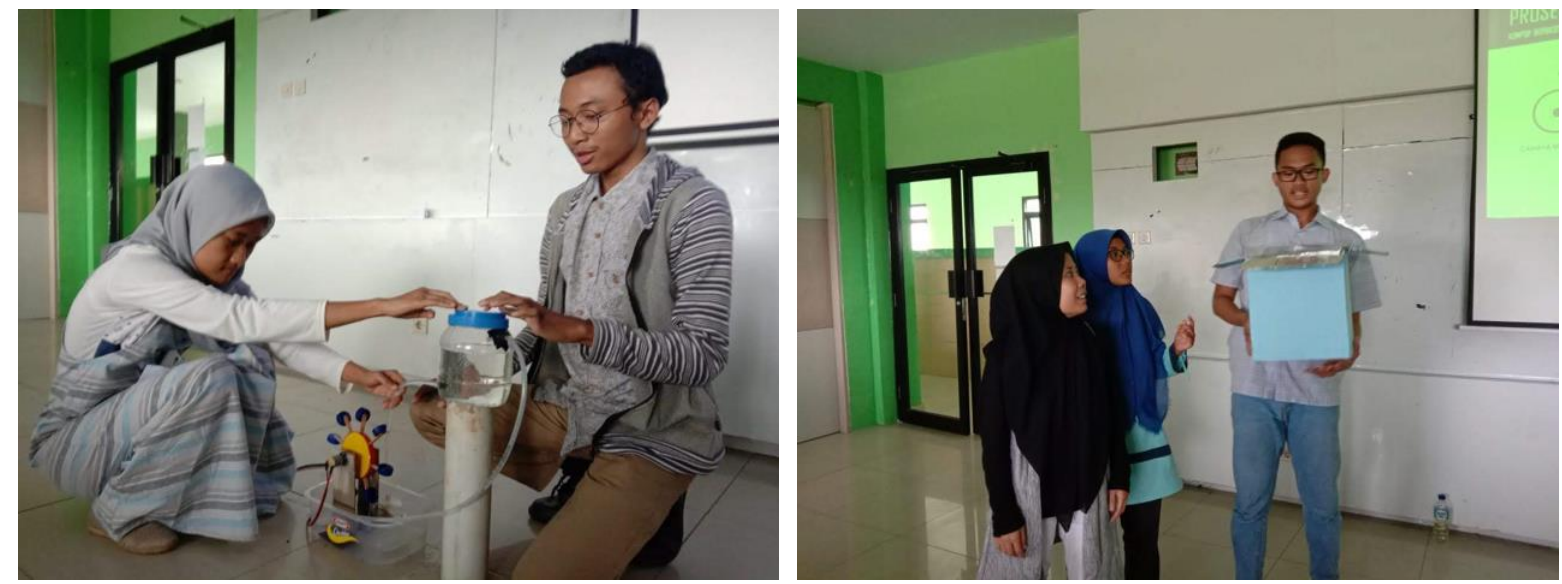

FIGURE 4. Products produced from STEM learning based on local fan diaries.

After the process of preparing all the components on the worksheet STEM local wisdom based on the material's temperature and heat for student-teacher candidates, Physics completely developed, then validated products. The development of local wisdom-based STEM worksheets has been verified in terms of material and media.

Subject matter experts provide ratings on MFIs STEM based on local wisdom is already meet the criteria are eligible with a percentage of $86.4 \%$ with a very decent interpretation on aspects of the 
suitability of content and language aspects. In contrast, the interpretation deserves to aspects of the presentation of the material order.

The results validate the feasibility of MFI STEM based on local wisdom by media experts shows the average percentage of $87 \%$ with inter achievement feasible.

\section{CONCLUSION}

Based on the results, it can be concluded that the worksheet STEM local wisdom based on the material temperature and cal or for student candidates Physics teacher-developed earn a percentage Sebes ar $86 \%$ by subject matter experts and $87 \%$ on a media expert. With the popularity scale feasibility stated that the worksheet STEM local wisdom based on the material temperature and cal or for student candidates Physics teacher developed a decent into learning media to increase interest and understanding of students through independent study. We recommend that products created by students be evaluated and improved to get the maximum product.

\section{ACKNOWLEDGMENT}

We acknowledge support from the Penelitian Kerjasama Antar Perguruan Tinggi - Universitas Sultan Ageng Tirtayasa under the contract number B/41/UN43.9/PT.01.03/2019.

\section{REFERENCES}

Afifah, R \& Ellianawati, E 2019, 'Student Cognitive Profile with STEM Based Teaching Material on the Subject of Vibrations and Waves', JPPPF (Jurnal Penelitian dan Pengembangan Pendidikan Fisika), vol. 5, no. 2, pp. 217-26.

Afriana, J, Permanasari, A, Fitriani, A 2016, 'Penerapan project based learning terintegrasi STEM untuk meningkatkan literasi sains siswa ditinjau dari gender', Jurnal Inovasi Pendidikan IPA, vol. 2, no. 2, pp. 202-12.

Asmawati, EYS 2015, 'Lembar Kerja Siswa (LKS) Menggunakan Model Guided Inquiry Untuk Meningkatkan Konsep Siswa', Jurnal Pendidikan Fisika Universitas Muhammadiyah Metro, vol. 3, no. 1 .

Astusi, Y \& Setiawan, B 2013, 'Pengembangan Lembar Kerja Siswa (LKS) Berbasis Pendekatin Inkuiri Terbimbing dalam Pembelajaran Kooperatif pada Materi Kalor', Jurnal Pendidikan IPA Indonesia, vol. 2, no. 1, pp. 88-92.

Bazelais, P \& Doleck, T 2018, 'Investigating the impact of blended learning on academic performance in a first semester college physics course', Journal of Computers in Education, vol. 5, pp. 67-94.

Branch, RM 2009, Instructional Design-The ADDIE Approach, Springer, New York.

Dewi, HR 2017, 'Peningkatan ketrampilan berfikir kreatif siswa melalui penerapan inkuiri terbimbing berbasis STEM', Prosiding SNPF (Seminar Nasional Pendidikan Fisika), pp. 47-53.

Ejiwale, JA 2012, 'Facilitating Teaching and Learning Across STEM Fields', Journal of STEM Education: Innovations and Research, vol. 13, no. 3, pp. 87-94.

Gunawan, G, Harjono, A, \& Sahidu, H 2018, 'Virtual Laboratory to Improve Students' Conceptual Understanding in Physics Learning', Journal of Physics: Conference Series, vol. 1108, no. 1.

Halim, L 2012, 'Mencetus SEMULA Minat Terhadap Sains dan Matematik melalui Pendidikan STEM', Kolokium Pendidikan Sains \& Matematik, UM 12-13 September 2012, National University of Malaysia.

Jufrida, J, Basuki, FR, Xena, A, \& Pasminingsih, P 2019, 'Gap Analysis and The Potential of Local Wisdom Jambi as Science Learning Resources', JPPPF (Jurnal Penelitian dan Pengembangan Pendidikan Fisika), vol. 5, no. 2, pp. 77-82. 
Muliyati, D et al. 2019, 'The implementation of project-based learning to enhance the technologicalcontent-knowledge for pre-service physics teacher in ICT courses', Journal of Physics: Conference Series, vol. 1521, p. 022023.

Nurdiansah, N, Kartadinata, S, Maryani, E, Supriatna, N, \& Priatna, T 2019, 'Collaboration learning: Local wisdom as source of science learning in elementary school', Journal of Physics: Conference Series, vol. 1318, p. 012125.

O'Dwyer, LM, Wang, Y, \& Shields, KA 2015, 'Teaching for conceptual understanding: A crossnational comparison of the relationship between teachers' instructional practices and student achievement in mathematics', Large-scale Assessments in Education, vol. 3, no. 1.

Parwati, NN, Tegeh, IM, \& Mariawan, IM 2017, 'Integrating the Values of Local Wisdom into the Learning Model: Building Positive Student Character', Educational Technology to Improve Quality and Access on a Global Scale, Educational Communications and Technology: Issues and Innovations.

Pertiwi, RS, Abdurrahman, A, \& Rosidin, U 2017, 'Efektivitas LKS STEM untuk Melatih Keterampilan Berpikir Kreatif Siswa', Jurnal Pembelajaran Fisika Universitas Lampung, vol. 5, no. 2 .

Stohlmann, M, Moore, TJ, \& Roehrig, GH 2012, 'Considerations for teaching integrated STEM education', Journal of Pre-College Engineering Education Research (J-PEER), vol. 2, no. 1, p. 4.

Wang, J, Wu, H, \& Hsu, Y 2017, 'Using mobile applications for learning: Effects of simulation design, visual-motor integration, and spatial ability on high school students' conceptual understanding', Computers in Human Behavior, vol. 66, pp. 103-13.

Yulkifli, Y, Ningrum, MV, \& Indrasari, W 2019, 'The Validity of Student Worksheet Using InquiryBased Learning Model with Science Process Skill Approach for Physics Learning of High School', JPPPF (Jurnal Penelitian dan Pengembangan Pendidikan Fisika), vol. 5, no. 2, pp. 155-62. 